\title{
THE TOPPLING OF AN IRRIGATION CENTER PIVOT SUBMITTED TO WIND ACTION EFFECTS
}

\author{
Edomir M. Schmidt ${ }^{1 *}$, Agenor D. de Meira Junior², Patricia C. Pedrali ${ }^{3}$, Antonio C. Valdiero ${ }^{3}$, \\ Nelson J. Thesing ${ }^{3}$
}

$1^{1 *}$ Corresponding author. Universidade Regional do Noroeste do Estado do Rio Grande do Sul/ Unijui, Panambi - RS, Brasil. E-mail: edomir.schmidt@unijui.edu.br | ORCID ID: https://orcid.org/0000-0003-0622-0437

\section{KEYWORDS}

toppling, stability, wind, pivot, irrigation.

\begin{abstract}
This research aims to improve the study about the stability of truss structures used in pivot irrigation, widely used due to the growing demand for food production, when submitted to wind effects. Specifically, it aims to verify the maximum wind speed supported by an irrigation center pivot structure when submitted to the load effects caused by wind gusts perpendicular to the equipment. In order to determine these forces and their effects on the irrigation equipment, computational numerical investigations were carried out using finite element bar models validated by measuring the natural frequency of the equipment in the field. A span was designed based on the existing standards in Brazil and the dynamic response of the structure was examined under the effects of wind gusts. Models of the Brazilian standard NBR $6123 / 88$ for structures submitted to wind effects were used in this study. The studied irrigation equipment supports wind gusts of up to $115 \mathrm{~km} / \mathrm{h}$ applied perpendicularly, with a duration of $3 \mathrm{~s}$, before generating toppling.
\end{abstract}

\section{INTRODUCTION}

Agriculture has a very important role in the Brazilian economy. According to Moreira et al. (2013), the planted area under irrigation corresponds to approximately 5.9\%, and the increasing search for quality products and productivity (Moraes et al., 2016) and increasingly competitive prices is incessant. In this sense, new technologies are sought in agriculture and irrigation plays an important role in this scenario, with more than 17 thousand installed equipment (Barbosa et al., 2018). Entrepreneurs seek technology and efficiency in irrigation to ensure the economic viability of agriculture (Sales et al., 2017), and the expansion of irrigated areas is proof of this need.

Center pivot sprinkler irrigation systems can be installed in small, medium, and large farmers in several regions around the world, enabling up to three crops per year (Almeida et al., 2018) and incorporating areas previously not recommended for planting (Vicente et al., 2018), especially in the South of Brazil, where rainfall is irregular (Martins et al., 2016). The areas for equipment installation have irregularities, slopes, gaps, and ditches, in addition to being exposed to winds, which have been registered more frequently in the South-Center region of Brazil (Hornes \& Balicki, 2018). According to Burlando et al. (2018), the main effect of air movement (or natural wind) is due to the heating of the Earth's atmosphere, starting with the pressure difference between points of the same height. These differences occur due to thermodynamic and mechanical phenomena occurring in the non-uniform atmosphere. Consequently, several natural manifestations caused by wind arise, such as the formation of cyclones, thunderstorms, rainstorms, tornadoes, etc. Wind can be classified according to its speed, as shown in Table 1.

\footnotetext{
${ }^{2}$ Universidade de Passo Fundo/ Passo Fundo - RS, Brasil.

${ }^{3}$ Unijui - Universidade Regional do Noroeste do Estado do Rio Grande do Sul/ Unijui, Panambi - RS, Brasil. 
TABLE 1 . Scales of wind intensity.

\begin{tabular}{ll}
\hline Classification & Speed (km/h) \\
\hline Week & $0-9$ \\
Moderate & $10-40$ \\
Strong (gust) & $41-60$ \\
Very strong (gale) & $61-90$ \\
Very strong (storm) & Above 91 \\
Hurricane & Above 115 \\
\hline
\end{tabular}

Source: Adapted from Burlando et al. (2018).

Piccardo et al. (2018) reported the main effects caused by the response of structures when submitted to the dynamic effects of winds, which is the kinetic energy of gusts on irrigation pivots. Because they are exposed to climate adversities, the toppling of irrigation pivots occurs caused by storms, although it is not widely reported.

Irrigation center pivots are designed for a useful life of 15 to 25 years. Therefore, operational costs must be foreseen with the wear of items that make up the system and that is directly related to the mechanical dimensioning, terrain relief, obstacles, and management. The irrigation center pivot system is composed of a fixed central tower, span or aerial part, and drive unit, where the wheelsets and overhung are included. The aerial part of the equipment, together with the drive unit, varies in quantity according to the size of the irrigated area, being able to reach 20 spans or 1000 meters of extension.

Figure 1 shows the structural model under study, in which the central tower has the function of fixing the equipment and allowing the entry of water to the aerial part, leading it to the overhung. The drive unit is responsible for the movement of the irrigation pivot around the central tower and the highest speed is in the final drive unit that sustains the overhung. The overhung is the final part of the irrigation pivot and has the function of increasing the irrigated area, being supported by cables that allow this structure to be suspended, allowing the passage in nonpassable points.

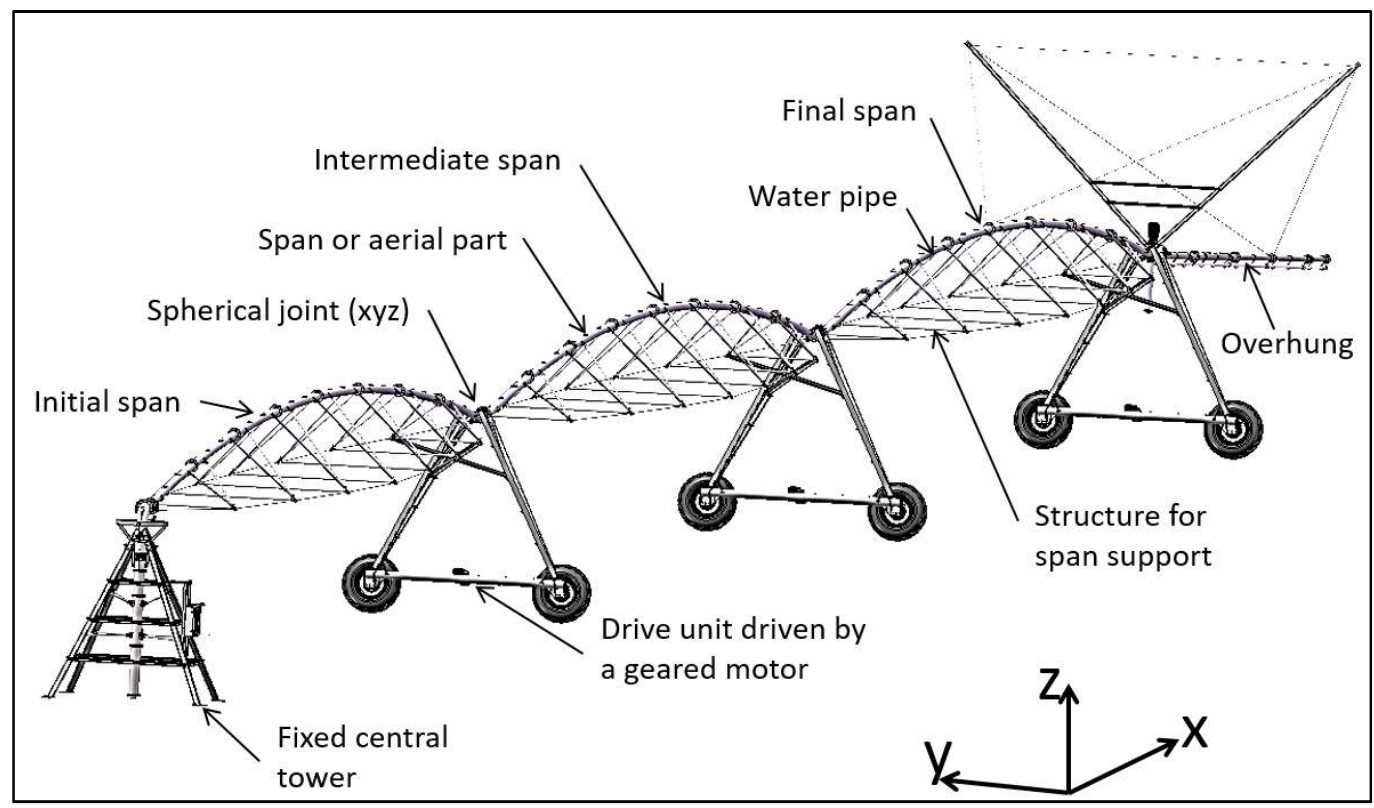

Source: The author.

FIGURE 1. Irrigation center pivot system.

The irrigation equipment is constructed with angle brackets, solid steel bars, and screwed tubes, as well as gear motors and wheelsets for moving the set and a control panel for control and programming of the equipment. According to the irrigated area, span lengths, which form the aerial part of the pivot, i.e. the distance between wheelsets, are scaled.
Figure 2 shows this dimensional variation between spans.

Due to the low equipment weight when compared to the wind attack area and the open field installation, irrigation pivots are subject to the action of strong winds that occur more and more often, causing the toppling of these structures. 


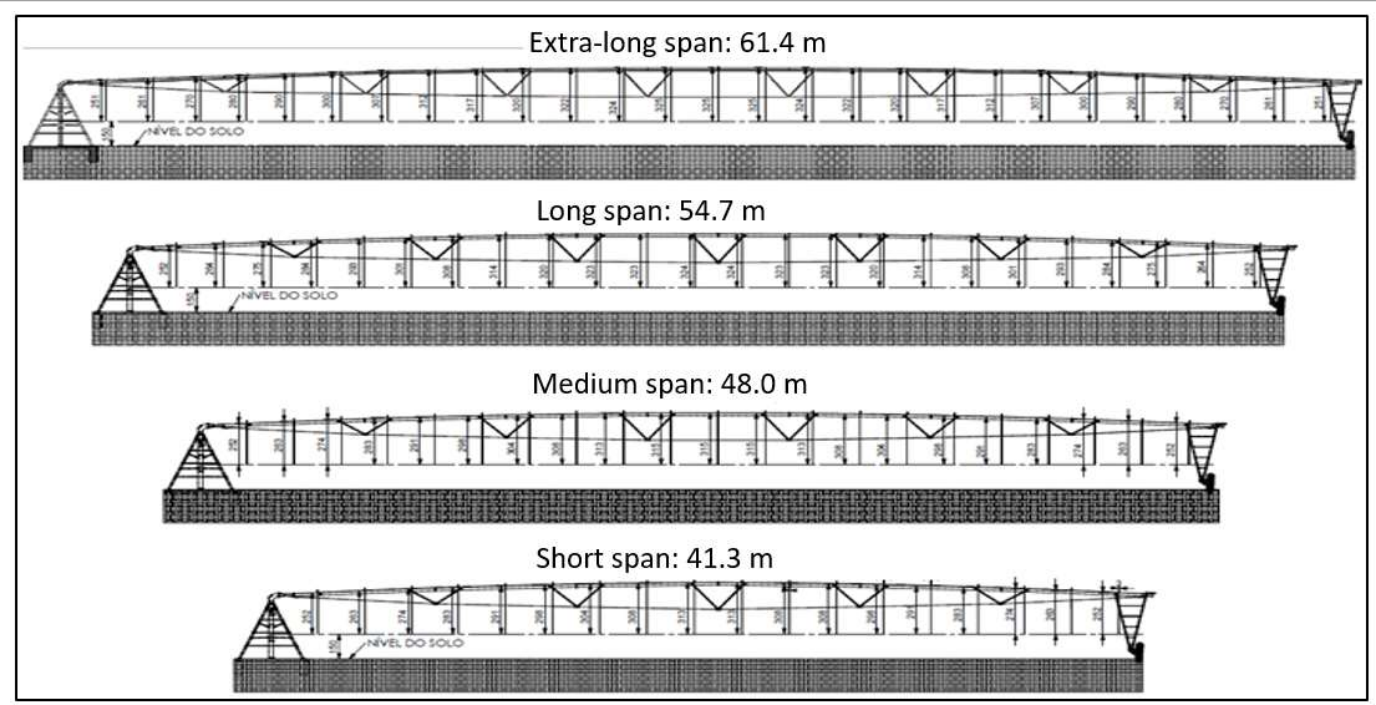

Source: The author.

FIGURE 2. Dimensional variation between spans of the center pivot.

\section{MATERIAL AND METHODS}

The study to analyze the maximum strength caused by different wind speeds perpendicular to the irrigation center pivot structure was developed by means of a numerical computational simulation of an equipment with one fixed central tower, three long spans, three drive units, three spherical joints, and one overhung, following the criteria of standard NBR 6123/88.

Figure 3 shows schematically the side and top views of the structural model under study, in which the three spans are in straight alignment, showing the transversal strengths caused by wind effects. Long spans, with 54.7 meters between the drive units, height of 3.5 meters until the beginning of the aerial part, 4 meters between the center of wheelsets, and 28 meters of overhung, were used in this study.

We considered that the irrigation pivot wheelset is passing on the same trail, on solid and dry soil. The soil was considered dry because most of the time the winds occur before the rain begins. Under these conditions, the adhesion coefficient is 0.8 and the contact area measured in the field is approximately $17600 \mathrm{~mm}^{2}$ per tire (Shao et al., 2017).

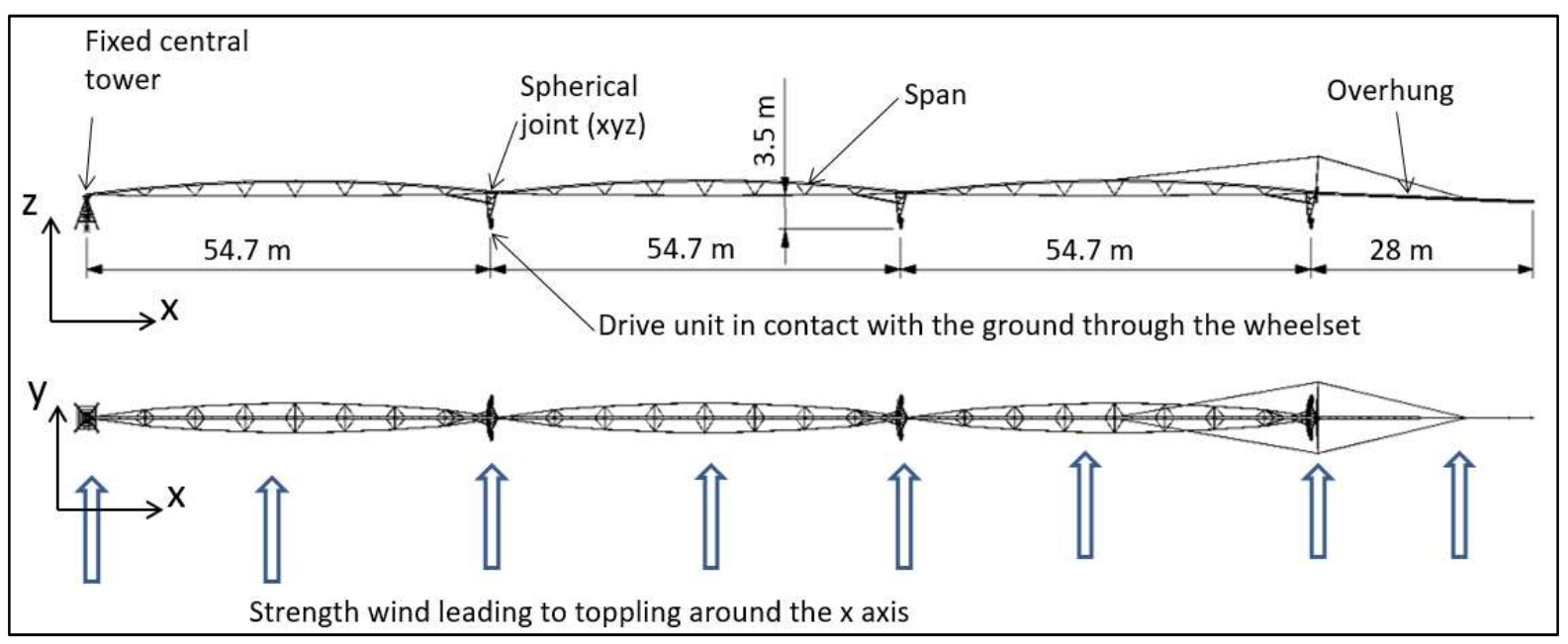

Source: The author.

FIGURE 3. Side view and top views of the irrigation pivot composed of three long spans and one overhung.

Wind strength intensity was defined according to the standard NBR 6123/88, in which the characteristic wind speed $W_{k}$ is given by [eq. (1)]:

$$
W_{k}=W_{0} S_{1} S_{2} S_{3}
$$

Where,

$W_{0}$ is the basic wind speed in $\mathrm{m} / \mathrm{s}$;

$S_{l}$ is the topographic factor, which takes into account the variations of terrain relief;
$S_{2}$ is the combined effect of roughness, variation of wind speed with the height above the terrain, and structure dimensions, and

$S_{3}$ is the statistical factor, which considers the required degree of safety and the useful life of the structure.

Irrigation pivot structure can be classified as a truss structure formed by circular section bars, in which the drag force $F_{a}$ is calculated by [eq. (2)] of the standard NBR $6123 / 88$ 


$$
F_{a}=C_{a} q A_{e}
$$

Where,

$C_{a}$ is the drag coefficient;

$q$ is the dynamic pressure, and

$A_{e}$ is the effective frontal area.

\section{Computational numerical model}

The computational analyses of the irrigation pivot regarding its stability in relation to the effects caused by wind were performed through the finite element program
ANSYS/LS-DYNA, obtaining results of its static and dynamic behavior and seeking the maximum wind speed that the equipment currently supports before the toppling moment is over.

Because the irrigation pivot consists of a large number of pieces (in this case more than 1000 pieces), modeling was performed in a simplified way. The complete modeling of the irrigation pivot structure is shown in Figure 4 , which shows the rigid support plane, which represents the soil, the $\mathrm{x}, \mathrm{y}$, and $\mathrm{z}$ positive axes, with origin point at the center of the fixed central tower, and the elements simulating the friction of wheels with the soil.

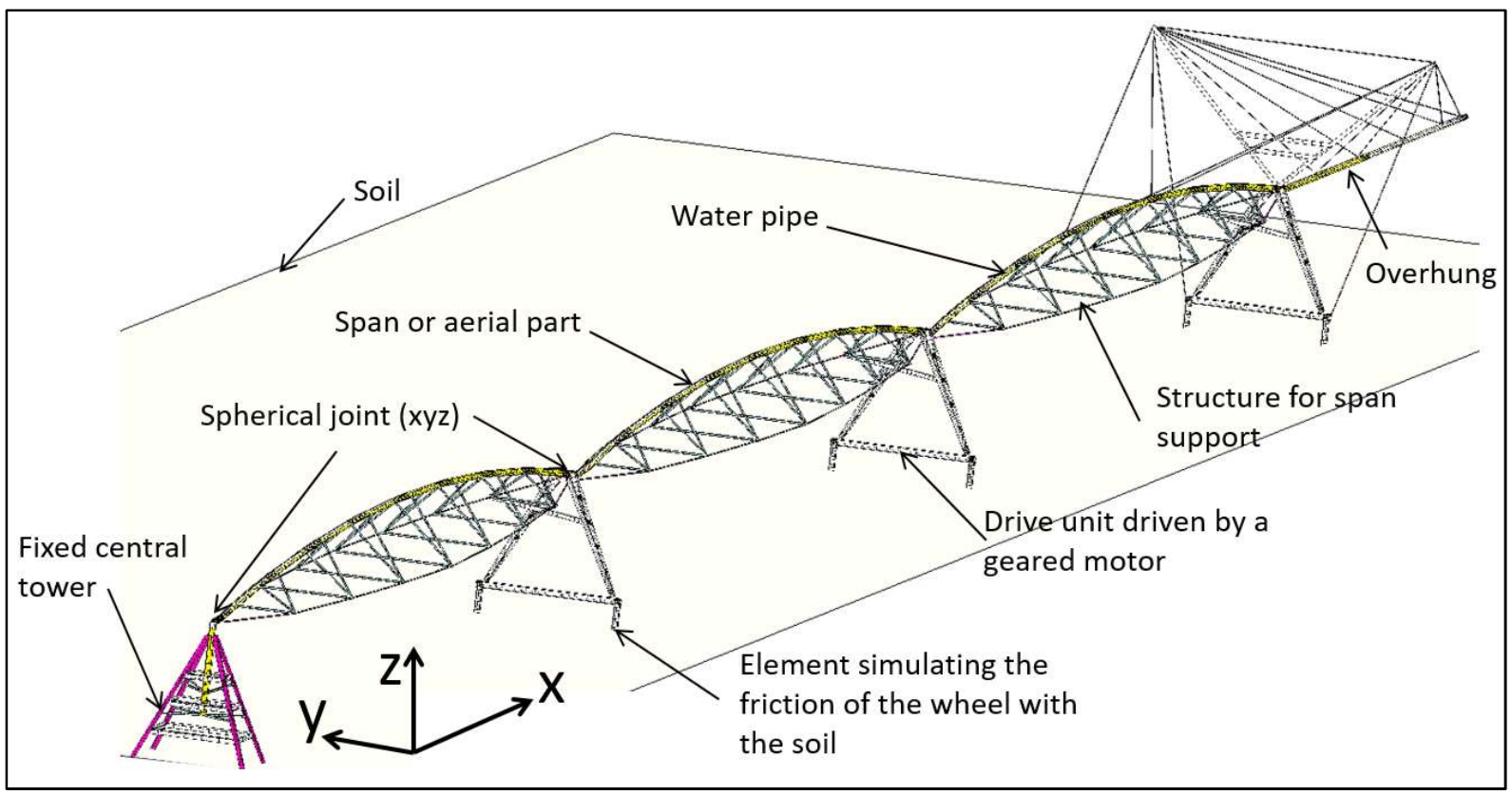

Source: The author.

FIGURE 4. Complete modeling of the irrigation pivot.

The beam elements that compose the irrigation pivot structure are formed by three nodes, with initial and final nodes, which define the dimensions and position of the element, and the orientation node, which is unique for each element. The $x$ axis is the longitudinal axis to the element, in which the cross-section belongs to the $y-z$ plane, as shown in Figure 5.

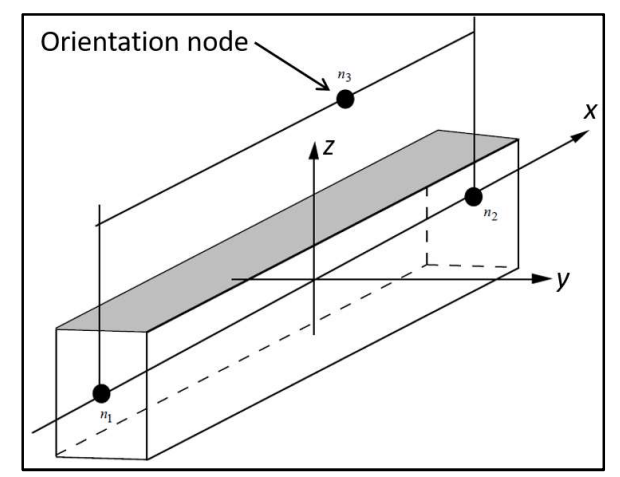

Source: LS-DYNA - Keyword User's Manual, 2003.

FIGURE 5. Beam element of LS-DYNA.

The drive units are joined by a spherical joint, which allows a rotational movement in $\mathrm{x}, \mathrm{y}$, and $\mathrm{z}$ between spans. Figure 6 shows a spherical joint considered in the numerical model. This joint does not allow a linear displacement, only rotation around the $\mathrm{x}, \mathrm{y}$, and $\mathrm{z}$ axes.

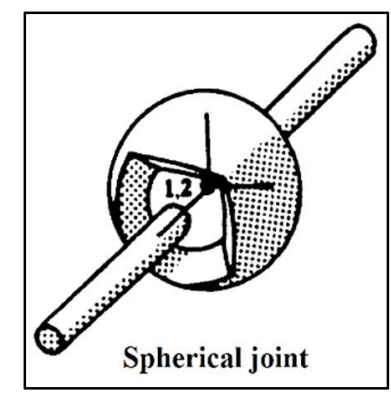

Source: LS-DYNA - Keyword User's Manual, 2003.

FIGURE 6. Spherical joint (LS-DYNA).

The steel used in the irrigation pivot was the SAE 1045 , which has flow stress of $320 \mathrm{Mpa}$, modulus of elasticity of $2.1 \times 10^{5} \mathrm{Mpa}$, Poisson coefficient of 0.3 , and density of $7.85 \times 10^{-6} \mathrm{~kg} / \mathrm{mm}^{3}$. Span pipes, through which the water passes, and tubes that form the truss had $2.65 \mathrm{~mm}$ of thickness. A steel cable was adopted for the cables that hold the overhung, considering an element per cable, with a $6 \times 7$-grade fiber core with a modulus of elasticity of $9.0 \times$ $10^{4} \mathrm{Mpa}$ and a density of $7.85 \times 10^{-6} \mathrm{~kg} / \mathrm{mm}^{3}$. 
The weight of the irrigation pivot consists of its structure mass. Wind-induced accidents occur when the equipment is not under operation, i.e. it does not contain water in the aerial pipeline. The equipment under study has approximately $7000 \mathrm{~kg}$, with $1150 \mathrm{~kg}$ in the central tower and $1950 \mathrm{~kg}$ in each drive unit, i.e. $975 \mathrm{~kg}$ per wheel. From the $975 \mathrm{~kg}$ that is on the wheel, $100 \mathrm{~kg}$ represents the mass of the wheeled set, which is composed of the wheel, rim, and wheel reducer and is inserted in the program as localized mass.

In order to evaluate the dynamic behavior of the irrigation pivot structure, modal analyses were performed to identify the different natural frequencies of the system. The model was constructed with beam elements, in which sections were assigned to different parts of the set, with approximately 8645 nodes and 4517 elements, having as boundary conditions the four points of support of the central tower that are fixed in $\mathrm{x}, \mathrm{y}$, and $\mathrm{z}$ and the six points of support of wheels, which have restriction of translation in $\mathrm{z}$ downwards and allow the translation movement in $\mathrm{x}$ and $\mathrm{y}$, with a coefficient of friction of 0.8 .
The modal analysis aims at identifying the natural frequencies of the overhung, final span, and intermediate span of the aerial part to be compared with the natural frequency of a real structure, constructed in the same dimensions, to validate the model.

\section{Experimental procedure}

In order to validate the proposed numerical model, an experimental study was carried out on the irrigation pivot structure with the same dimensions used in the numerical model. In this test, the value of natural frequencies of the equipment was identified in practice, in which the excitation was performed similarly the numerical model.

Accelerometers were installed at the end of the overhung, in the aerial tube in the middle of the final span, and in the aerial tube in the middle of the intermediate span of the irrigation pivot in order to carry out the practical tests (Figure 7), being applied an initial strength to the structure and then it was released, generating vibration.

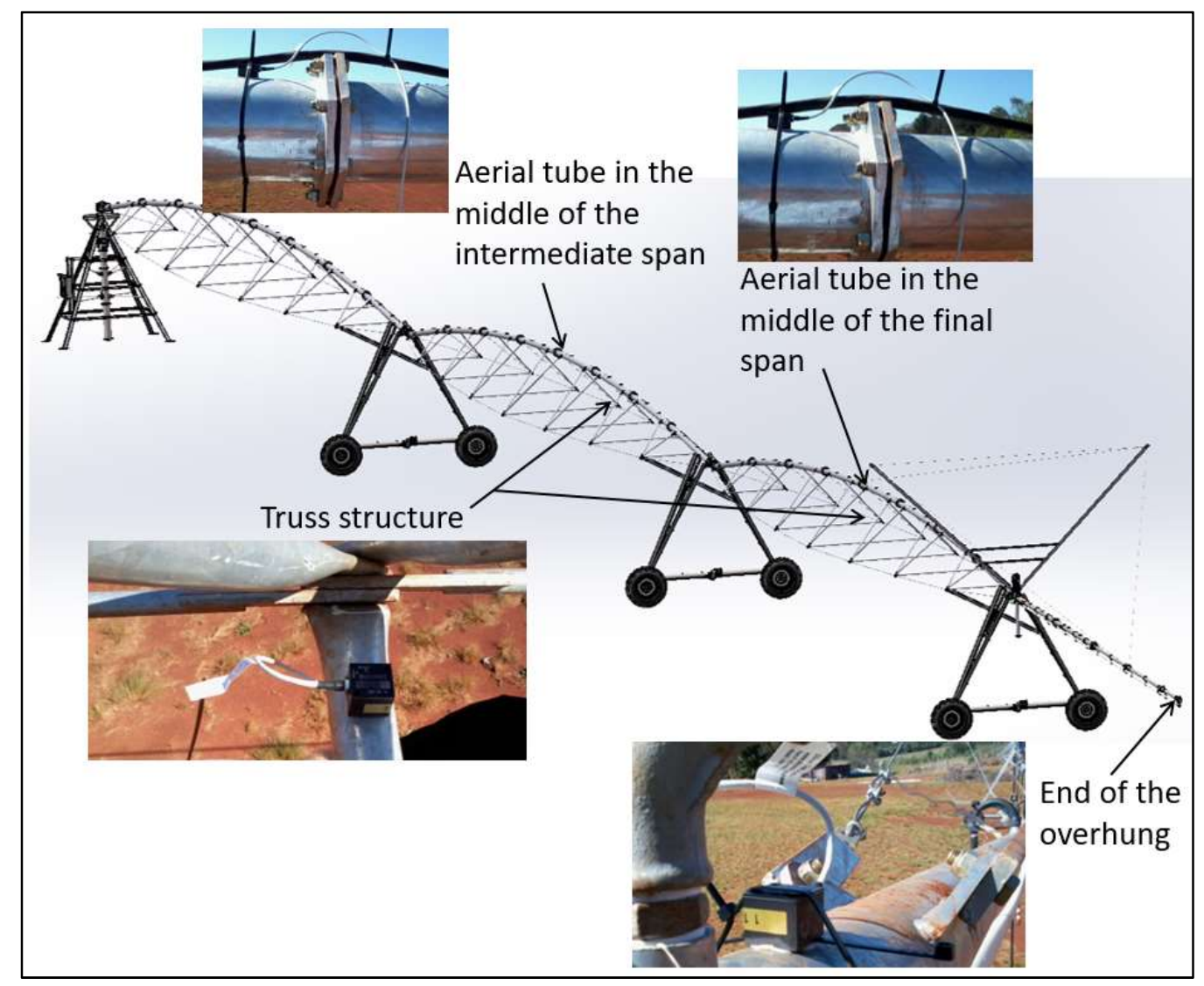

Source: The author.

FIGURE 7. Accelerometer installation points in the experimental test.

Frequency measurement was carried out with a Silicon Designs 2460-010 analogical triaxial accelerometer and an HBM MGCplus data acquisition and amplification system (http://hbm.com) was used to read the data.

\section{Dynamic analysis}

The dynamic analysis showed the maximum wind speed that the supported by the irrigation equipment before the toppling moment is over. Wind strengths, which are defined according to the criteria of the standard NBR
6123/88 and according to wind attack area, were applied. The time used for analysis was 6.05 seconds. The load was applied in the first 3 seconds since it is the approximate time of wind gust, while the other 3.05 seconds was without load, considering a friction factor between wheel and soil of 0.8 .

\section{RESULTS AND DISCUSSION}

Table 2 shows the comparison between natural frequencies generated by the numerical model and natural frequencies measured in the equipment in practice. 
TABLE 2. Comparison between natural frequencies of the numerical model and measurements in practice.

\begin{tabular}{lcc}
\hline \multicolumn{1}{c}{ Vibration mode } & $\begin{array}{c}\text { Natural frequencies of the } \\
\text { numerical model (Hz) }\end{array}$ & $\begin{array}{c}\text { Natural frequencies of the } \\
\text { equipment in practice (Hz) }\end{array}$ \\
\hline Horizontal overhung vibration & 0.95 & 0.7 \\
Vertical overhung vibration & 1 & 0.75 \\
Final span vertical vibration & 1 & 1.1 \\
Final span torsional vibration & 1.4 & 1.35 \\
Intermediate span vertical vibration & 1.5 & 1.3 \\
Intermediate span torsional vibration & 1.3 & 1.3 \\
\hline
\end{tabular}

Source: The author.

Figure 8 shows that the results have a good agreement, demonstrating that the numerical model has a behavior close to that of the irrigation pivot in practice and can be used in the dynamic simulation.

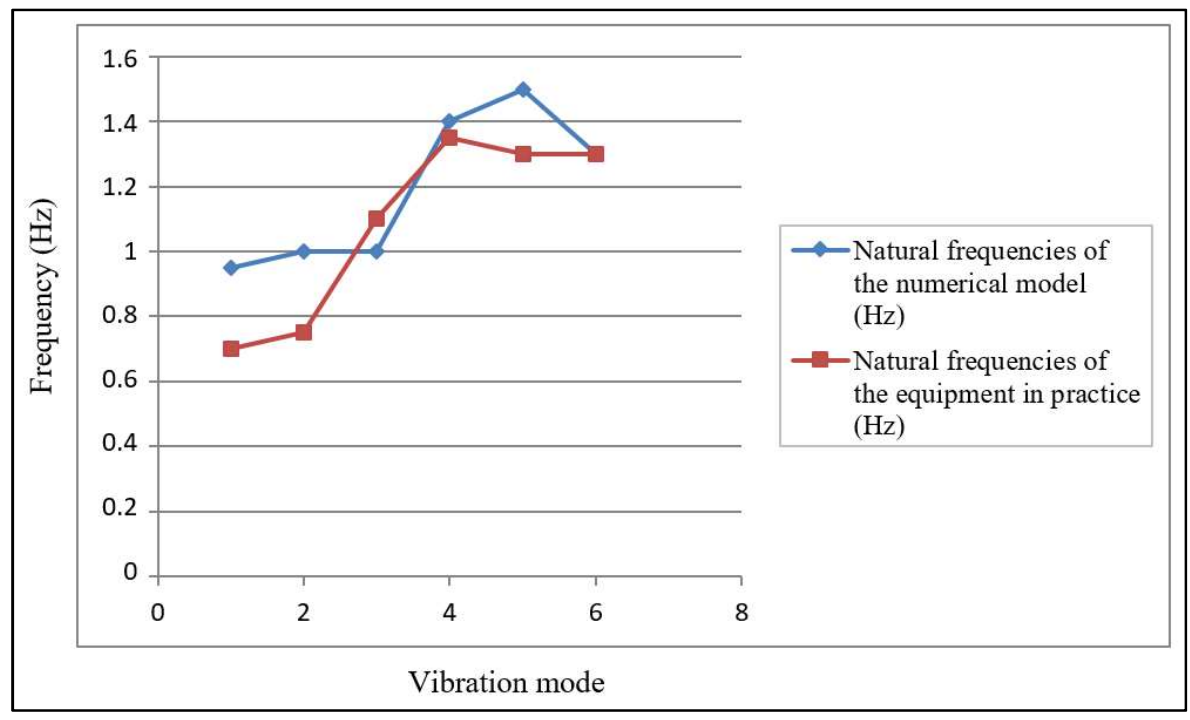

Source: The author.

FIGURE 8. Comparison between natural frequencies of the numerical model and measurements in practice.

Strength intensity was defined according to the standard NBR 6123, in which the wind limit supported by the structure before the toppling moment is over was $115 \mathrm{~km} / \mathrm{h}$ and generated a total strength of $24704 \mathrm{~N}$. Table 3 shows the strength per node for each component of the structure for speeds of 115 and $116 \mathrm{~km} / \mathrm{h}$.

TABLE 3. Distribution of the strength applied to each node of the structure for different speeds.

\begin{tabular}{cccccc}
\hline & \multicolumn{2}{c}{ Irrigation center pivot } & \multicolumn{2}{c}{ Strength per node for different speeds $(\mathrm{N})$} \\
\hline Description & Diameter $(\mathrm{m})$ & Total area $\left(\mathrm{m}^{2}\right)$ & $\mathrm{N}^{\mathrm{o}}$ of nodes & $115 \mathrm{~km} / \mathrm{h}$ & $116 \mathrm{~km} / \mathrm{h}$ \\
Aerial tube & 0.165 & 30.954 & 434 & 28.7043644663419 & 29.2057412672285 \\
Triangle A & 0.0424 & 1.536576 & 84 & 12.2699952937446 & 12.4843143041684 \\
Triangle B & 0.0424 & 1.821504 & 84 & 14.5452262091409 & 14.7992864930208 \\
Triangle C & 0.0424 & 2.0352 & 84 & 16.2516493956882 & 16.5355156346601 \\
Triangle D & 0.0424 & 1.058304 & 42 & 16.9017153715157 & 17.1969362600465 \\
Rod & 0.01905 & 6.1109352 & 476 & 8.61133257753273 & 8.7617460236885 \\
& 0.1016 & & & & 36.3203728966378 \\
Tower & 0.0381 & 5.69 & 107 & 35.6968587662035 & \\
\end{tabular}

Source: The author.

Figures 9 and 10 show the maximum displacement generated by the application of load caused by a wind gust with a duration of $3 \mathrm{~s}$ and speed of 115 and $116 \mathrm{~km} / \mathrm{h}$, respectively. In the second case, the final span toppled and hence the maximum speed supported by the current equipment is $115 \mathrm{~km} / \mathrm{h}$. 


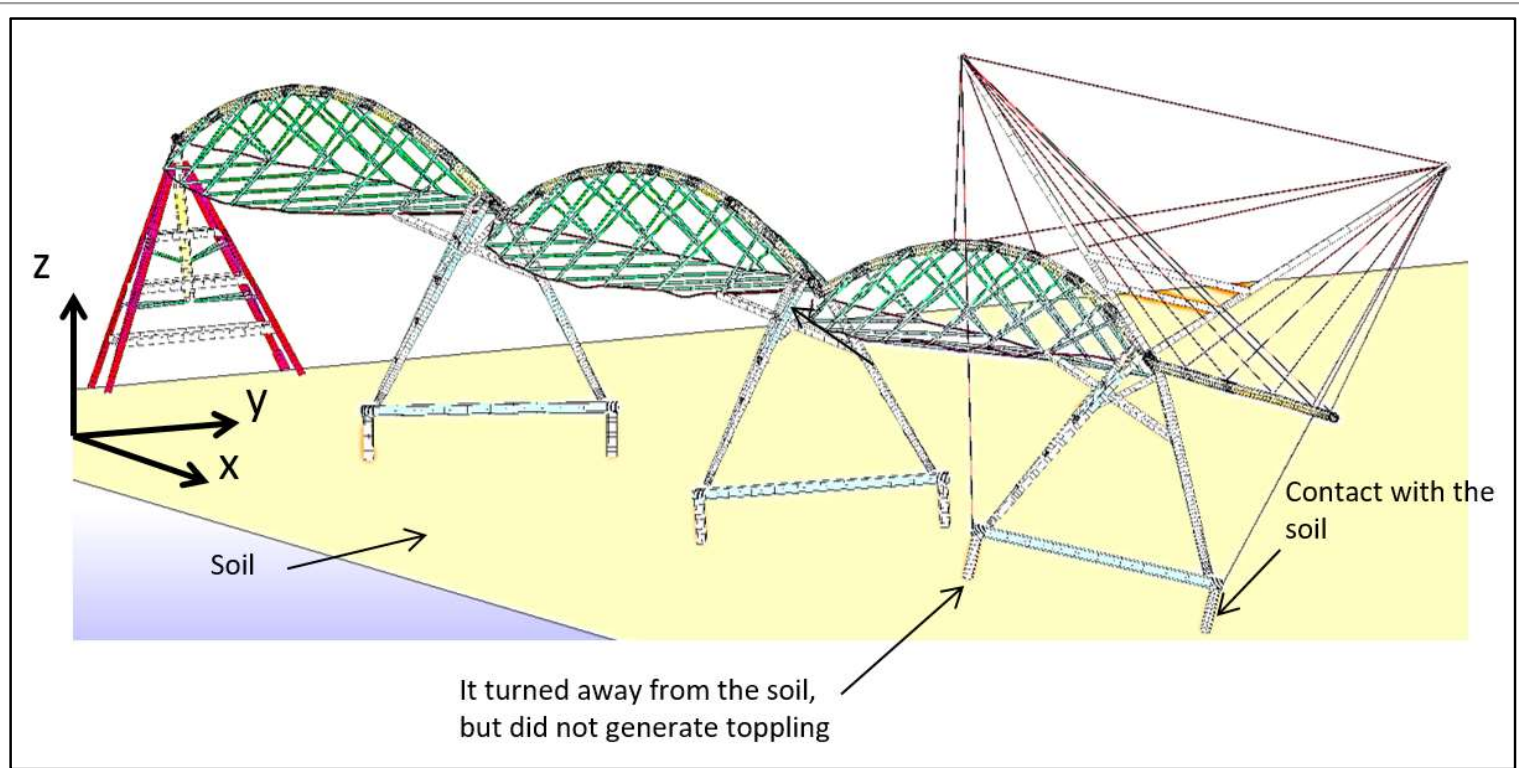

Source: The author.

FIGURE 9. Maximum displacement at $115 \mathrm{~km} / \mathrm{h}$.

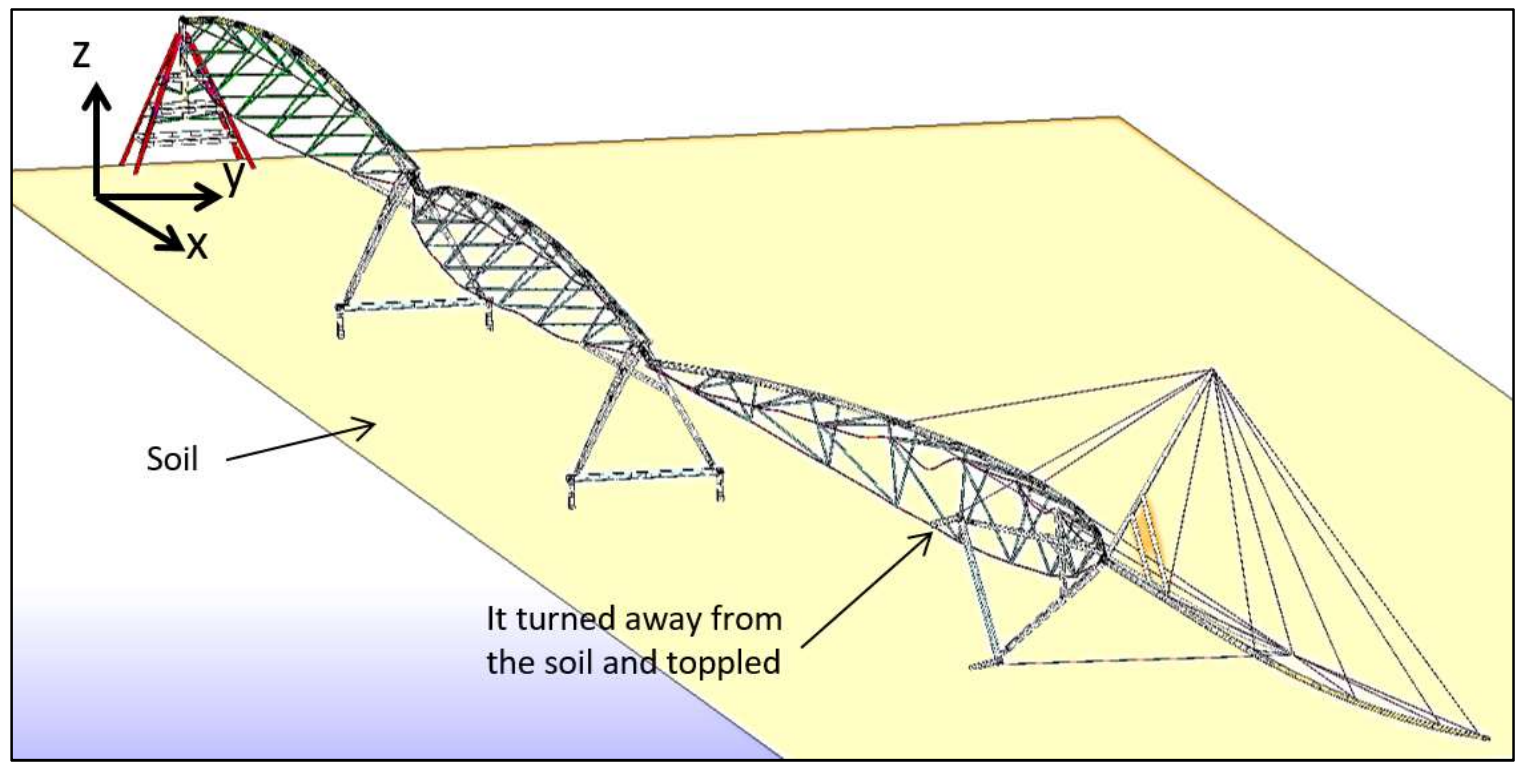

Source: The author.

FIGURE 10. Toppling of the final span at $116 \mathrm{~km} / \mathrm{h}$.

\section{CONCLUSIONS}

Through wind-resistance simulations of a truss structure formed by circular-section tubes submitted to the dynamic effects of the wind using the relationship between the strength caused by wind gusts and the toppling moment, obtained from the analysis of finite element bar models validated by comparing the modal analysis of the model with an equipment in practice, allowed identifying the maximum wind speed supported by an irrigation pivot before toppling.

\section{REFERENCES}

Almeida V, Júnior JA, Mesquita M, Evangelista AWP, Casaroli D, Battisti R (2018) Comparação da viabilidade econômica da agricultura irrigada por pivô central emsistemas de plantios convencional e direto com soja, milho e tomate industrial. Global Science And Technology 11(2):256-273.
ABNT - Associação Brasileira de Normas Técnicas (1988) NBR 6123: Forças devidas ao vento em edificações. ABNT.

Barbosa BD, Colombo A, de Souza JG, Baptista VBDS, Araújo A (2018) Energy efficiency of a center pivot irrigation system. Engenharia Agrícola 38(2):284-292. DOI: http://dx.doi.org/10.1590/1809-4430eng.agric.v38n2p284-292/2018

Burlando M, Zhang S, Solari G (2018) Monitoring, cataloguing, and weather scenarios of thunderstorm outflows in the northern Mediterranean. Natural Hazards and Earth System Sciences 18(9):2309-2309. DOI: http://dx.doi.org/10.5194/nhess-18-2309-2018

Hornes KL, Balicki M (2018) Caracterização do tornado ocorrido em Marechal Cândido Rondon e Quatro Pontes em novembro de 2015. Raega-O Espaço Geográfico em Análise 44:36-54. DOI: http://dx.doi.org/10.5380/raega.v44i0.47761 
Martins JD, Bohrz IS, Tura EF, Fredrich M, Veronez RP, Kunz GA (2016) Levantamento da área irrigada por pivô central no Estado do Rio Grande do Sul. IRRIGA 21(2):300-3011. DOI:

http://dx.doi.org/10.15809/irriga.2016v21n2p300-311

Moraes MJ, Oliveira Filho D, Mantovani EC, Monteiro PMB, Mendes ALC, Damião JHAC (2016) Automação em sistema de irrigação tipo pivô central para economia de energia. Engenharia Agrícola 34(6):1075-1088.

Moreira J, Rodrigues L, Zanatta J, Torres MDO (2013) Planejamento de irrigação em pivô central por meio de modelos matemáticos. In: Simpósio Brasileiro de Recursos Hídricos. Bento Gonçalves, Associação Brasileira de Recursos Hídricos, Proceedings...

Piccardo G, Poggi S, Solari G (2018) Some critical issues on the distribution of the maximum value of the windexcited response of structures. Probabilistic Engineering Mechanics 54:65-81.
Sales DLA, Junior JA, Pereira M, Rodriguez WDM, Casaroli D, Evangelista AWP (2017) Viabilidade ecônomica da irrigação por pivô central nas culturas de soja, milho e tomate. Pesquisa Agropecuária Pernambucana, 22(u):1-6. DOI: http://dx.doi.org/10.12661/pap.2017.011

Shao M, Kishimoto T, Satow T, Takeda J, Way TR (2017) Traction and braking force on three surfaces of agricultural tire lug. Engineering in Agriculture, Environment and Food 10(1):39-47. DOI:

http://dx.doi.org/10.1016/j.eaef.2016.07.002

Vicente MR, Mantovani EC, Fernandes ALT, Delazari FT, Figueredo EM (2018) Efeito de diferentes lâminas de irrigação nas variáveis de desenvolvimento e produção do cafeeiro irrigado por pivô central. IRRIGA 20(3):528-543. DOI: http://dx.doi.org/10.15809/irriga.2015v20n3p528 